\title{
When Working Abroad Becomes a "Dosa" (Sin): The Impact of Women's Migrant Domestic Labor on the Gender Relations in Rural Indonesia
}

Quand travailler à l'étranger devient un péché (Dosa) : L'impact du travail

d'employé de maison des femmes immigrées sur les relations entre les hommes et les femmes dans l'Indonésie rurale

Cuando trabajar en el extranjero se convierte en un pecado (Dosa): El impacto del trabajo doméstico de las mujeres migrantes sobre las relaciones de género en la Indonesia rural

\section{Keiko Hirano}

\section{(2) OpenEdition}

\section{Journals}

Electronic version

URL: https://journals.openedition.org/remi/7179

DOI: $10.4000 /$ remi.7179

ISSN: $1777-5418$

Publisher

Université de Poitiers

Printed version

Date of publication: 1 January 2015

Number of pages: $57-79$

ISBN: 979-10-90426-24-5

ISSN: 0765-0752

\section{Electronic reference}

Keiko Hirano, "When Working Abroad Becomes a "Dosa" (Sin): The Impact of Women's Migrant Domestic Labor on the Gender Relations in Rural Indonesia ", Revue européenne des migrations internationales [Online], vol. 31 - $n^{\circ} 1 \mid$ 2015, Online since 01 January 2018, connection on 19 April 2022. URL: http://journals.openedition.org/remi/7179 ; DOI: https://doi.org/10.4000/remi.7179 


\section{When Working Abroad Becomes a "Dosa" (Sin): The Impact of Women's Migrant Domestic Labor on the Gender Relations in Rural Indonesia}

\section{Keiko Hirano ${ }^{1}$}

\section{Introduction}

As globalization has advanced, Indonesia has focused on following the lead of the Philippines as a sending country. In 2011 , about $70 \%$ of Indonesian migrant workers, new hires, were women. Until then, "men were the breadwinners as the head of the household" (Indonesian Matrimonial Law, Article 1), but in these new circumstances in which women have taken the role of breadwinner, what is the impact of this change on the social and economic condition of the migrant household? Will women migrant workers negotiate to acquire a new status based upon their upwardly mobile economic status? Will male migrants' families try to regain their forfeited status in some way? What role will the sending community play in reconfiguring gender relations in the sending household?

In the field of migration studies, an abundance of previous studies have examined the issue described above (George, 2011; Hochschild, 2000 ; Ito and Adachi, 2008). In particular, Ito and Adachi (2008) articulated the relationship between gender and migration in Japan under the impact of globalization in terms of the "international division of reproductive labor." As well as George (2011) discussed, based on their detailed fieldwork, professional labor migration in which nurses immigrate before their families, thereby transforming gender relations and class dynamics, which in turn alters households and immigrant communities.

In other areas of research, which consider migration from the perspective of the sending country, Indonesian migrant workers have been investigated, such as the harsh conditions in which women migrant laborers work or how they work outside of labor regulations in destination countries. Also, previous studies have pointed out the delayed political response to migrant labor issues by the Indonesian government as compared with the governments of other sending countries, such as the Philippines (Hirano, 2009 ; 2013 ; Irianto, 2011 ; Ueno, 2011.

1 Specially appointed associate Professor, Hokkaido University of Education, 1-2,

Hachiman-cho Hakodate Hokkaido, 040-8567, Japan; hirano.keiko@h.hokkyodai.ac.jp 
In this context, this paper discusses the research questions stated above, that is, how the "feminization of migration" defines gender relations in the sending household and community in a case in Cianjur Province, West Java, Indonesia, and whether these relations are renegotiated in the household and the community. This research, which is based on semi-structured interviews and in-depth interviews with migrant women, male family members who are left behind by women migrants, and religious leaders, was conducted intermittently between 2008 and 2012. I cite several narratives but use pseudonyms when referring to the subjects of this paper.

For this analysis, I use Connell's framework, that is, gender regime. Connell ([2002]2008) presented the whole social patterns as gender order of society. In a society, we can find out a pattern in gender arrangements which is called gender regime of an institution, such as who was recruited to do what work. She proposes four dimensions as the basis for gender relations, which are power relations, production, emotional relations, and symbolism relations (culture, discourses). When an institutional pattern reflects a particular gender configuration, Connell named this pattern the "gender regime" (Connell, 2008: 97-117).

Understanding a gender regime as a theoretical framework can help us explain how women's role can be explained in the spheres of production/ reproduction, home, and community, as well as in state development policy. The concept of gender regime provides a useful analytical perspective on how the pattern of the division of labor has been determined according to how women's body is situated within each sphere listed above. As to the issue of female domestic workers crossing borders, I look at religious discourses and the response to them regarding the representation of women migrant workers' body in discussing the sending community with Islamic values as an example of globalization.

In this paper, I analyze the two gendered structures of labor and power to see how they shape gender relations in the lives of women's migrant workers in the sending community and how they prescribe religious discourses and the way in which it is practiced by women migrant workers and their male family members in their home and the sending community in line with religious discourse or not.

I examine the research questions stated above by studying the case of women migrant workers and their male family members in one of the largest communities that sends domestic workers to the Gulf countries, Cibinong City, Cianjur West Java, Indonesia.

\section{Work: Placement of Indonesian Migrant Workers and the Impact of Decentralization}

To discuss the work sphere, we need first to outline Indonesian labor migration policy. Since 1969, as a strategy for national development, the government of Indonesia has been sending a large number of migrant workers outside the country. The government set concrete numerical targets and then the "placement of Indonesian labor migrants" rapidly grew, especially following the 
Third National Development Plan (1979-1983/4) when President Raden Suharto sought to establish domestic political and social stability through economic development.

In the background, there was a redundancy of domestic labor. The unemployment rate was $19 \%$ in urban areas and $24 \%$ in rural areas in 1976 . Unemployment became critical, especially in rural areas, in 1980, when it was $17 \%$ in urban areas and $27 \%$ in rural areas (Indonesia Departemen Penerangan, 1985: 261). In addition, the oil shock of 1973 significant impacted overseas migration. Labor shortages in the Gulf countries, which were a result of the oil shock, led to a need for construction workers not only from within the Gulf areas but also from the Southeast Asian countries. In this situation, the Indonesian government fell behind the other sending countries, such as Thailand and the Philippines, which had already established aggressive placement policies (Robinson, 2000: 253). According to data gathered by the Ministry of Labor Force and Transmigration (Departemen Tenaga Kerja dan Transmigrasi), the Indonesian government set the numerical target of international migrant workers at 100,000 people in 1979 , although it did not achieve this target. During the next period of the national development plan (1984-1989), the target was set at 220,000, and in fact, over 290,000 people entered the migration labor market (Table 1).

Table 1: Placement: Indonesian Migrant Workers

\begin{tabular}{|c|c|c|c|}
\hline Year & Female & Male & Total \\
\hline $1969-1974$ & $*$ & $*$ & 5,624 \\
\hline $1974-1979$ & 3,817 & 12,235 & 16,052 \\
\hline $1979-1984$ & 55,000 & 41,410 & 96,410 \\
\hline $1984-1989$ & 198,735 & 93,527 & 292,262 \\
\hline $1989-1994$ & 442,210 & 208,962 & 651,172 \\
\hline $1994-1998$ & 699,946 & 349,681 & $1,049,627$ \\
\hline $1999-2004$ & $1,206,103$ & 446,120 & $1,652,223$ \\
\hline $2005-2009$ & $2,458,375$ & 773,678 & $3,232,053$ \\
\hline 2010 & 451,120 & 124,683 & 575,803 \\
\hline 2011 & 376,027 & 205,054 & 581,081 \\
\hline 2012 & 109,130 & 78,929 & 188,059 \\
\hline Total & $6,000,463$ & $2,334,279$ & $8,340,366$ \\
\hline
\end{tabular}

${ }^{*}$ no data

Source: BNP2TKI (Research center of development and information 1994-2010), BNP2TKI GOID (Placement based on gender 2006-2012).

As shown in Figure 1, the destination countries indicate a wide distribution throughout the world, such as Asia, the Middle East and Europe. For example, in 2012 , we see that both the regions of Asia (50.2\%) and the Gulf countries $(49.2 \%)$ constitute nearly all of the immigration. In particular, immigration to Malaysia 
(39.7\%) and Saudi Arabia (45.2\%) ranks at the top, and this trend has continued from 1994 to the present.

Figure 1: Destination by Region

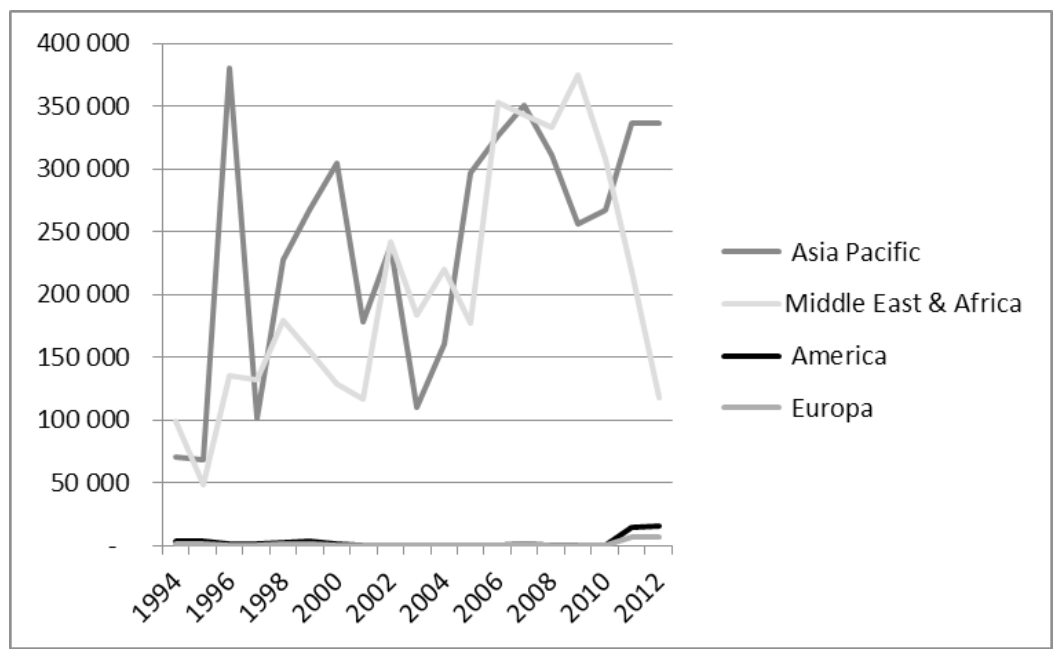

Source: BNP2TKI (Research center of development and information 1994-2010), BNP2TKI GOID (Placement based on gender 2006-2012).

Figure 2 shows that, as in other sending countries, more and more feminization of migration has occurred among Indonesian migrant workers since the 1970s (Table 1, Figure 2).

Figure 2: Indonesian Migrant Worker's Placement Based on Gender

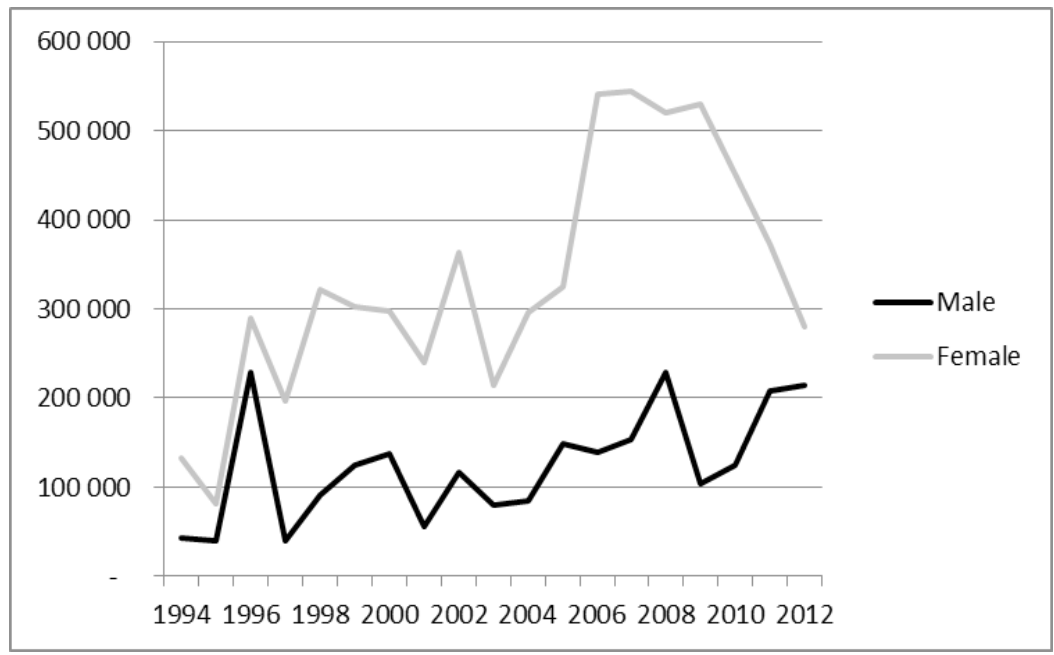

Source: BNP2TKI (Research center of development and information 1994-2010), BNP2TKI GOID (Placement based on gender 2006-2012). 
Regarding the sending of migrant workers to the Gulf countries, when their number skyrocketed in 1983, the Indonesian government approved private recruitment operations (Robinson, 1991). This period already marked the end of the construction boom in the Gulf countries, which had needed male migrant workers before 1983; thus, the Indonesian government made a drastic policy shift, from sending male migrants as drivers and gardeners to sending female migrants as domestic workers. This was a positive change, as both Pakistan and Bangladesh prohibited resident migrant workers, and the Philippines also restricted the number of laborers it sent to other countries (Miyamoto, 2000).

Indonesia is the most populous Muslim country in the world; therefore, the Gulf countries, and Saudi Arabia specially, appeal to prospective migrant workers, as this destination country embraces the Holy City of Mecca. Even if workers were never allowed to leave the employer's house once a day, Saudi Arabia as destination country would be quite attractive to them (Miyamoto, 2000; Robinson, 2000). A hajj visa is issued when pilgrims head off to a holy place, which also offers an incentive for these workers to migrate to the Gulf countries.

Indonesian migrant workers' occupational placement is divided into two categories: the formal sector and informal sector. The formal sector in Indonesian statistical terms denotes the labor category that is employed by organizations such as a company, restaurant, factory, and hospital. In contrast, the informal sector denotes the labor category that is employed in individual homes. For example, although a migrant driver is categorized in the formal sector if he is employed by a company, he is also considered part of the informal sector if he is hired by an individual household.

As shown in Table 2, almost all migrant workers in the Gulf countries are female domestic workers. These workers, then, make up $90 \%$ of the informal sector, and nearly all of them are domestic workers (Table 2).

Table 2: Number of Male and Female Migrant Workers by Formal and Informal Sectors 2005-2008

\begin{tabular}{|c|c|c|c|c|c|c|}
\hline \multirow{2}{*}{ Year } & \multicolumn{2}{|c|}{ Formal } & \multirow{2}{*}{$\begin{array}{c}\text { Formal } \\
\text { total }\end{array}$} & \multicolumn{2}{|c|}{ Informal } & \multirow{2}{*}{$\begin{array}{c}\text { Informa } \\
\text { total }\end{array}$} \\
\hline & Male & Female & & Male & Female & \\
\hline 2005 & 136,607 & 60,267 & 196,874 & 12,658 & 264,778 & 277,436 \\
\hline 2006 & 112,975 & 64,520 & 177,495 & 25,025 & 477,480 & 502,505 \\
\hline 2007 & 132,755 & 63,436 & 196,191 & 20,131 & 480,423 & 500,555 \\
\hline 2008 & * & * & 269,577 & * & * & 479,248 \\
\hline
\end{tabular}

${ }^{*}$ no data

Source: BNP2TKI Research center of development and information. 
These migrant workers send remittances back home, and the amount has steadily grown each year. These monies accounted for $0.8 \%$ of GDP in 2013, which is 88 trillion 670 billion Rupiah (7.88 billion US dollars) ${ }^{2}$. The amount of the remittances has also increased, although the amount sent by overseas migrant workers has been decreasing as a portion of GDP, as Indonesia has shown steady economic growth since 2004 in the post-Suharto era.

As described in this paper, West Java dominates as a sending area for migrants to the Gulf countries. This trend can be attributed to the commercialization of labor migration that developed after the 1980s rather than to geographical factors. As will be discussed in later, it would be safe to say that domestic workers who migrate to the Gulf countries are less educated, and that this relatively low educational background prevents them from going to other destination countries such as Singapore, Hong Kong, and Taiwan, which pay high salaries than the Gulf countries. Recruitment agencies screen these workers according to their educational background. Usually prospective workers are required to have more than a high school diploma to be sent to high salary destinations. In contrast, workers sent to the Gulf countries do not have any requirements regarding their academic training. Rather, their experience as foreign domestic workers, rural origins, and competency in communication in Arabic are highly valued. Also employers appreciate the employee's obedience toward their "master." They do not, however, consider the employee's education, although it is noted in her resume ${ }^{3}$.

The lower educational requirements for migration to the Gulf countries highly facilitate this international migration, especially that of female migrant workers, as we see in A village, Cianjur, West Java, where about $80 \%$ of the population have a primary school education.

\section{Religion: Decentralization and Representation of Female Migrant Workers}

The institutionalization of otonomi daerah (decentralization) has been cited as proof of democratization in Indonesia, in contrast to the Suharto regime, which pushed bureaucratic centralization. One of the significant arguments in the favor of decentralization is the opportunity for local governments to enact their own regulations. Indonesian central government under Suharto regime did not recognized the establishment of ordinances by local governments. In local municipalities such as provinces, prefectures/counties, and cities, the implementing agency only authorized them to implement the budget provided by the central government, as instructed. However, B. J. Habibie, who succeeded Suharto, undertook decentralization as a way of securing legitimacy without holding elections, which included a budget prepared by the local government, communal elections, and the enactment of local regulations. Areas rich in natural resources, such as Aceh and Papua, sought to have this policy enforced,

2 See: http://www.thejakartapost.com/news/2014/01/13/ri-migrant-workers-remittancesamounted-rp-886t-2013.html (last accessed June 3 2015).

3 March 11, 2013, in Abu Dhabi. 
and it was supported as a form of democratization assistance by the international society.

Turning from the implementation of democratization, let us now consider putting into place local regulations. Currently in Indonesia, we can see many Islamization of local regulations ${ }^{4}$. Among these are some rules that restrict the diversity prescribed in the constitution and that are controversial in terms of gender. For example, Poerwandari (2007) pointed out that gender segregation, which could even be called "gender backlash," in the Islamic local regulations has arisen with decentralization. Citing Muliah (2006), Poerwandari showed that 56 not gender-sensitive regulations have been implemented in cities in Indonesia since July 2006. Citing some specific examples, such as a female public officer must wear the jilbab (veil) (East Java, 2002), and a curfew is imposed on females who go out alone in public with the aim of preventing prostitution (Tangerang, West Java 2005), she discussed the trends in local regulations that apply Islamic law as the norm to female bodies (Poerwandari 2007: 16).

In the case of Cianjur, West Java, we can recognize another manifestation of Islamization of law, (Local Regulation in Cianjur no.3 year 2006, about social development movement for good personality; Perda no. 3). Perda no. 3 stipulates that ethical orthodoxy based on religion, especially Islam, should be the guideline for people in every area of life, including politics, education, law, and the daily living environment. This has led to female students in educational institutions in Cianjur being required to wear the veil. Also, it has been suggested that, according to Perda no. 3, female staff members in government offices should wear the veil.

The Islamization of movement in Cianjur has also influenced women's migration practices in all of the processes involved in going overseas to work. The director of the Indonesian Ulema Council (Majelis Ulama Indonesia: MUI), who jointly enacted Perda no. 3 with the Cianjur Governor, replied to my question that is; "Does the labor migration of lone female migrants infringe Islamic law?" by saying that "it should be considered haram (a taboo under Islamic law) as judged according to the spirit of this Perda."

Forty-eight Islamic organizations in Cianjur, including the MUI, joined together to enact this Perda. These organizations considered this action as an effort to implement Islamic legal practices, and the MUI formulated the drafts of each article. Also, it was necessary to focus on costs to advance this Perda, which requires promotional staff and costs around 3 million Rupiah annually to pay staff salaries. This amount of the salary per person is not sufficient to support an individual; however, what is noteworthy in terms of the Islamization of local regulations in Indonesia is that this item is included in the budget.

Regarding the placement and protection of the migrant worker, Cianjur passed other regulations, and it had already enacted these in 2002 before the implementation of the domestic law ${ }^{5}$. Perda no. 15 places an obligation on the

\footnotetext{
4 August 25, 2012, Jakarta-Shimbun (Jakarta Newspaper).

5 Local regulation in Cianjur no.15, year 2002, about protection of Indonesian overseas migrant workers from Cianjur; Perda, no.15. This Perda revised as: in Cianjur no.1,
} 
migrant workers and concerned parties throughout the process involved in placement (Article 2 ) to comply with the regulations based on religion and moral and ethical codes. Given the current progress in Islamization in the sending areas, as noted above, women laborers who migrate alone are thus considered as committing a "transgression."

Obviously the MUI's opinion does not indicate the general position of society at large on women's migrating overseas alone. Furthermore, Islam is not monolithic. Nahdlatul Ulama (NU), which is the largest Islamic organization in Indonesia, has expressed the opinion that it is not necessary to take a positive or negative stand on this issue. Kiyayi, who is a familiar Islamic religious leader at the community level for migrant workers and their families, has stated that the migration of lone women migrants should be allowed unless men in rural areas are unemployed for long periods of time.

However, we should note how these patriarchal discourses within a religious atmosphere define the migration of lone women migrants, and this is a significant argument. As previously discussed, migrants from Cianjur cross the border of Indonesia when heading to the Gulf countries, and the majority of them are women who are alone and plan to work as domestic laborers. Under the power of this magnetic attraction, that is based on centralized national development, has become fragmented, and Islamization has taken over in the name of democratization, which means that overseas migration by lone women migrants is not allowed, how do their cross-border practices have an impact on their household, community, and themselves?

We return here to the initial question. When women become economically and nominally dominant as "the primary breadwinner for their family" (Marriage Law, Article 31), does the international migration of lone women migrants affect their social and economic conditions and their household? Do women leverage their improved economic status and bargain for greater gains in their home and communal sphere? Also, do men especially, who are left behind by their wives, try to regain their forfeited position as the household head in some way? What is the role of their sending community and does the communal sphere transform conventional gender relations in this space?

\section{Overseas Migration in A village: Formation of Labor Recruitment Circuit}

I discuss the issue above by citing a case that exemplifies the practices of women migrant workers and their male family members in A village, Cianjur, West Java, that is, when women become primary breadwinner of their family, what the impact toward their ${ }^{6}$ own family, community is. Also what is the role of community regarding transforming conventional gender relations?

A village is located in a mountainous area, and in September 2011, it had a population of 5,027 people, in 1,239 households. This village's main industry

year 2012, about protection of Indonesian overseas migrant workers from Cianjur; Perda no.1, in 2012. 
is agriculture, and therefore, Cianjur is known ${ }^{7}$ as one of the most prolific riceproducing areas $^{8}$. The village started sending migrant workers abroad in the late 1970s. Until the mid-1980s, overseas migration was mainly seen as a form of commuting that pilgrims undertook to their employer's home in A village ${ }^{9}$. Other, domestic, workers who had formerly had jobs in metropolitan areas such as Jakarta and Bandung, returned to their hometowns and visited recruitment offices on their own that were located in the center of Cianjur and in eastern Jakarta, took pretraining for around 3 months before migrating, and then went abroad to work. Although it cost about 250,000 yen to migrate with a "pilgrim" visa, this was a very popular way for the upper-middle class to afford these expenses because it was possible to get a "hajj" visa and earn back these costs through commuter migration ${ }^{10}$.

In the mid-1980s, a trend spread to A village in which local recruiters (calo, sponsor) in the sending areas became part of the migration process, that is, they introduced prospective migrant workers to employment agencies in metropolitan areas and received a fee as the broker ${ }^{11}$. This corresponds to the time when the number of placements of migrant workers drastically increased beginning in the middle of the 1980s, and the "feminization of migration" in Indonesia is reflected in national statistics (see Table 1).

We need to pay attention to this particular time period, when the circle was closed between the sending community and migration industry in Indonesia. This time coincided with the farmers relinquishing their agricultural land in $A$ village. As discussed above, the agricultural sector still dominated over $80 \%$ of the industry in A village in 2011. However, the number of landless farmers was increasing. This trend is seen in West Java, which is one of the heaviest riceproducing areas. When the farmers gave up their land and become landless migrants, the inflation in the post-Suharto era severely damaged their daily lives.

Until the late 2000s, the dominant practice was for a calo to come to A village directly and provide intermediary services to prospective migrant workers. Potential female migrant workers who aimed to be domestic workers in destination countries did not have to pay for their migration costs, while, in contrast,

7 West Java provided $16.9 \%$ of the domestic rice demand in 2013 (Badan Pusat Statistik 2014: 195).

8 Agriculture, 83\%; public official, 12\%; army/police, $2 \%$; pastoral, $1 \%$, in 2007. Data from A village office.

9 Pilgrims to Mecca have two ways in which to do this: the "hajj pilgrimage" and other types of pilgrimage. The hajj pilgrimage occurs between the eighth and the thirteenth days of the last month in the Islamic calendar, and is the fifth and last Pillar of Islam. Men who had make a hajj pilgrimage are called Haj, and women are called Haja, and they both earn the respect of society. Muslim countries allocate a quota for hajj pilgrims every year.

10 In A village Cianjur, West Java, November 3, 2008. In 2008, Ms. Yayat, who is thirty years old, traveled to Saudi Arabia by umroh visa and was forcibly sent back after working as a domestic worker for 1 year. Her mother also tried to obtain a job by getting an umroh visa.

11 NGO staff (Solidaritas Buruh Migran Cianjur: SBMC) who support migrant workers in Cianjur at Ms. Dede's home, November 24, 2008. According to Ms. Dede, A village started sending migrant workers via recruiters in about 1982. She has worked as a domestic worker for 7.5 years in Saudi Arabia, since 1993. 
men who aimed to be drivers had to cover these costs on their own. By taking their future pay workers to cover migration costs, that is, by withholding the costs from workers' wages for about three months (such as for airline ticket, insurance, fees for a health checkup before crossing the border), the recruitment agency could accommodate the increased demand for domestic workers in destination countries. Once village women decided to become overseas domestic workers, their social and economic situation compelled them go abroad on their own without any preparation, even though they lived in poverty ${ }^{12}$. They could send remittances after six months; therefore, labor migration became a reasonable choice for people at the lowest social and economic rung as a means of survival. The industrialization of migration, including recruiters (calo), significantly contributed to the reconfiguration of industry in A village.

\section{How Women Migrant Workers Are Stigmatized?}

Here we discuss how patriarchal religious discourses characterize lone female labor migrants in the case of $A$ village. At $A$ village, we can point out two practices regarding women's lone labor migration as described by women migrant workers themselves. The first example is the surat ijin suami/keluarga (permission letter by husband/family) that is provided by the husband or a male family member. Prospective women migrant workers submit this letter to the local recruiter to demonstrate that they have permission from their male family members, especially their husband, to migrate. The 2004 Law 2 that regulates the placement and protection of international migrant workers does not obligate either prospective migrant workers to provide this letter or recruiters to require it; however, everywhere in A village, Cianjur and Karawang district, West Java, we can see that it is a customary practice in the migratory process. By submitting this letter ensures "there is the guardians with lone female migrant workers exceptionally." Also, in negotiating with their husband or a male family member to write the letter, workers are then psychologically motivated to remit their salary to their families. Yayah, who has migrated three times to Saudi Arabia, told me, "When we go abroad, we need to get permission from our husband, inevitably it means automatically we take responsibility to send the remittance, don't we?"

In the second example, we see the practice of women becoming divorced before they cross the border. This practice prevents women migrant workers from incurring public blame, such as being labeled "immoral wives," and also makes it possible to diminish their husband's sin for not migrating with his wife. Yayah, who is mentioned above, received the following advice from a local religious leader when she was in the process of migrating: "If you would go

12 However, because of an incident regarding the recruiter problem, which was reported by the media, the method of recruiting migrant workers was changed after Law number 39 on the Protection and Placement of Indonesian Workers of 2004 and Presidential Regulation No. 81, regarding the National Board for Placement (BNP2TKI) of 2006, were enacted. Since a report that reviewed the presidential decree pointed out the recruiter issue, BNP2TKI and the Department Labor have worked at eliminating recruiters. This action that was taken by a government agency has led to a decline in the number of recruiters in a sending community. Therefore, prospective migrant workers now directly go to a recruitment company in the center of Cianjur and Jakarta, as they already know which company will be able to assist them with their needs. 
abroad alone, you should offer divorce to your husband, it is primary before going to a recruitment agency"13. From the perspective of Islamic practice in Indonesia, getting divorced is not difficult for either party, as it is an adjunctive as well as a communal custom. Prospective migrant workers and men who are left behind by their wives bring an application of divorce to the office of the department of religious affairs (Kantor Urusan Agama), which is generally located next to the regional government office and then it is sent to the court if the office fails to make a determination. The divorce certificate is issued on the basis of a court decision ${ }^{14}$.

Under the migration practice in A village that women usually go abroad after their marriage, the migration of lone female alone to work means delinquency by the wives as prescribed in Article 33 of the Marriage Law. By impinging on law and religious norm, women-headed migration households violate the code of conduct regulated by the sending community. Therefore, we can see the customary practice that prospective migrant women try to get a "permission letter" and divorce before going overseas in this sending village.

However, despite the practice in which some women get divorced before leaving the village, most migrant women nevertheless travel to the destination country while still retaining their married status, and this cross-border practice that they engage in to earn a living is criticized and stigmatized by the religious authorities. We can see the stigma that is placed on women for this action in the following narrative by a migrant woman:

"We (migrant women) all are dosa. My body, in migrating as a domestic worker, is committing a sin, and committing an action that is religiously prohibited (haram). "

All the interviewees, who comprised fourteen participants in focus group discussions organized by the author in A village, and eleven people who agreed to do an in-depth interview, mentioned the relationship between the crossborder actions they have taken and the sexual stigma imposed on them ${ }^{15}$. In Indonesia, the term dosa is implies both a religious sin and a crime, whereas haram means a behavior forbidden by Islamic law. The migrant women referenced both of these terms to explain their stigmatized body.

13 At my rented room in A village Cianjur West Java, on February 9, 2009.

14 Some of the grounds for divorce are an act of unchastity, abandonment in bad faith, imprisonment, abuse, inability to carry out one's obligations as a husband or wife, and one spouse or the other is unable to carry out his or her duty as husband or wife. "Duty" here for the husband means the "husband takes good care of the wife, and to the maximum extent, he is obliged to provide what his family needs in daily life (Marriage Law, Article 34, Paragraph 1), and the male's duty is based on this paragraph, i.e., membiayai keluarga (provide for the family). The spouse who has requested the marriage will receive the buku nikah (marriage book) if the couple applies for a marriage license.

This book shows the man's responsibility as it relates to living expenses, i.e., the wife possesses the right to plead for the dissolution of the marriage if the husband does not give her a sum to live on for more than three months.

15 I conducted these interviews intermittently between November 2008 and March 2009. Most interviews were carried out in the room I rented in the SMBC staff's house, and they usually lasted one to three hours. I met with some of the interviewees several times to hear their stories. 
We can similarly find a sexual stigma in the narratives of other women who do not migrate from A village. For example, there is the case of Kodir and Awat, who are "people who do not migrate." This couple has ten-year-old and twoyear-old daughters, and they make a living doing agricultural work, in addition to occasionally doing carpentry. Although they have not experienced migration, Kodir did work in construction, building a hotel in Jakarta when he was between seventeen and nineteen years old. Furthermore, Awat took a job as a domestic worker in Jakarta at age fifteen, after she married, but she returned to the village after just three months. They both have relatives and close friends who migrate abroad, and also know other villagers who do so. Awat's sister-in-law has seven years' experience in Saudi Arabia as a domestic worker, and a close friend of Awat has traveled to the Gulf countries three times for her work. Although the couple has these personal connections to those who have worked abroad, they consider that women migrants' overseas work, especially as the breadwinner, would be haram for them.

"Dosa (shouldered by migrant women) means that women leave their husband. It means the same as abandoning one's obligation as a wife. They know they caused this abandonment themselves [...] well, it is haram that women make a living as the family head."

Another topic that needs to be discussed concerns the dosa and haram of migrant women. This issue is related to the perceiving the body of domestic workers, especially in the Gulf countries. In Indonesia, the media has intermittently reported on the treatment of Indonesian migrant workers in destination countries, Gulf countries in particular, since the $1980 \mathrm{~s}^{16}$. The women migrants featured in the media are typically "poor" domestic workers who face difficulties with arrears, abuse, imprisonment, and the ultimate penalty, which is being brought home, from the Gulf countries and the neighboring country, Malaysia (Robinson, 2000). Unwanted pregnancy is one topic that has been highlighted by the media, and viewers can see the unregistered Indonesian-Arabic children in this sending village. The migrant women's families lead an unacceptable existence. To enter school, they need their birth certificates; however, most of these documents are not made, which results in their citizenship becoming a critical migrant issue in the sending country of Indonesia. These situations are sufficient to establish the basis for the sexual stigma of "unmobile people" in a sending area.

\section{What Are Stigmatized: Men in Family of Migrant Women}

The sexual stigma imposed on migrant women simultaneously brings about another stigma for their male family members.

Based on the scattered representations of "poor" domestic workers that can be found in newspaper articles, a certain image is evoked, especially among men in urban areas, of economically poor women who are sold into slavery

16 Newspaper articles, such as Antara (January 26, 2012), Jakarta Globe (June 20, 2011; June 30, 2011), Koran Tempo (September 15, 2011). 
in the Gulf countries. Furthermore, this image creates an insulting view of the male family members who are left behind by migrant women. For middle-class men in urban areas, the representation of the "poor" domestic worker and the demasculinized domestic worker's husband is a result of screening how husbands of migrant workers fulfill their duties as ideal Muslim men ${ }^{17}$. In the present study, based on the absentee interviewees and the questionnaires that were not submitted, it is clear that male interviewees in urban areas do not necessarily know that the salaries of domestic workers are prescribed by law, and that in addition these are above-average wages.

However, comments from men in urban areas, such as "If I were a husband of a woman who wanted to migrate, I would not let her or my sisters and daughters go abroad to do hard work," obviously show their incomprehension of not only the situation of "poor" domestic workers, but also of household in rural areas generally that produce migrant women.

"Why do men [who are left behind by domestic workers] in rural areas not try to go to metropolitan areas and seek a job? If they would come here, they could easily find any job they want. Husbands will not take responsibility as the ketua keluarga (household head) because they are just waiting for a remittance from the wife. "

Here, we can see dosa (sin) toward rural men who might not fulfill their duty as a "family breadwinner" as the household head. In fact, the narrative quoted above emphasizes their acts of religious omission as the breadwinner. In other words, the image is that of a demasculinized and second-class rural man's dosa (sin). Middle-class men in urban areas attach perceived images of men as "demasculinized" to male family members of migrant women who live in rural areas. Moreover, they are represented as "religiously improper people" by "unmobile people" in sending areas such as that of Kodir. Let us quote another remark by this couple:

"It is their dosa (sin), very much [they give permission to their wives to go overseas as domestic workers]. The husband sells his wife."

Women's migration and the agreement by the men in their family to their crossing over to another country to work is perceived as amounting to selling (menjual) wives for the "unmobile" Kodir. In A village, overseas external work is not seen as a path toward economic upward mobility by community members, even though the economic disparity is clear between households that embrace migrants workers and households that have no labor migrants. This difference is reflected in the owning of real estate and personal possessions, such as houses, dish antennas for receiving television signals in mountainous villages located at 1,200 meters, and motorbikes, which help provide people with mobility in locations where public transportation is almost nonexistent. Such consumer

17 I conducted absentee interviews regarding migrant women using questionnaires with 208 men in urban areas. Interviewees are 208 men in Jakarta, Bogor in province West Java, Depok in province West Java, and Tangerang in province Banteng. They are office workers, public officers, teachers, and assembly members at the municipal and provincial level. They answered, "Husbands do not fulfill their duty as men" (this was the majority of responses for those in all types of jobs), rather than "it is dosa (sin) that women leave their husband" (nearly $10 \%$ in all types of jobs). 
items are all obtained through labor migration; therefore, we almost always find these possessions in the migrant's household. It is possible to see in A village two lumbering factories which is one of the successful big businesses funded by migrants' remittances.

Changes in economic status that are created through the labor migration of domestic workers are not understood as economic upward mobility, not only by the middle class but also the "unmobile" villagers who stigmatize these individuals with such labels as a "poor domestic worker" or a "husband who sells his wife." The term "demasculinized husband of a domestic worker" reflects doublesided stigma, which is a gendered occupation, that is, a domestic worker.

It is through various sorts of religious discourses used in religious ceremonies, as discussed below, that these efforts at stigmatizing men who are left behind by migrant women are strengthened. Here, we consider these religious discourses and reflections by male family members of migrant women with regard to the breadwinner discourse. An assembly for men is held in A village on Independence Day-August 17-and every Friday for prayer at the mosque. Friday prayer is offered in congregation, and Muslims are required to assemble in the mosque on that day. In A village, one or two mosques have been built in every Rukun Tetanga (neighborhood community association: RT) ${ }^{18}$, and it is possible to see male villagers going to the neighborhood mosque around noon. Friday prayers offer the imam a chance to advise all Muslims, and his sermon allows him to issue guidance on Islamic teachings. In addition, the mosque offers a space for teaching Arabic literacy and Islamic doctrine to preschool-age children. Regarding gender norms and daily practices, such as how men and women are supposed to behave, the mosque gives lectures to people from early childhood, both at home and in religious spaces.

"I was taught by the imam as a child: it is the male's responsibility to build a house and also to provide clothing and food. "

The statement that male responsibilities are taught beginning in childhood refers to migrants' overseas work, which is a common daily scene in this village. An 'Aalim (Islamic scholar) gives a sermon sometimes about how men and women are supposed to behave regarding remittances.

"Remittances by wives should be used with propriety. It is the husbands' duty whose wives work abroad as domestic workers. Make an effort not to become disenchanted with your wife after her return home. Because of the husband's embezzlement during her absence, male family members show up for a consultation."

A male staff member at an active legal aid office in the center of Cianjur explains that three out of the four cases he dealt with in January 2013 were divorce petitions from wives who had gone abroad to do domestic work and whose husband had embezzled the funds they sent back ${ }^{19}$. These practices seem

18 A village consists of four Rukun Warga (neighborhood associations: RW) and 19 RT. 19 Kampung cerai gara dari Saudi. Selama aku di kerja LSM ini, sudah kali menguurus penceraian, karena hutan, uangnya dimakai oleh suami dsb. Semuanya TKW itu (at a male staff member's house, in A village Cianjur, West Java, February 13, 2013). 
to begin the subversion of gender relations between a migrant worker wife and her husband in this sending village-through religious sermons as well as legal practices.

However, for the husbands concerned, it is nothing more than a bingun (embarrassment), even if they are told that their wives' migrating alone to work is haram according to the influential Ulema Council. Furthermore, the wives' body is suddenly represented as "stained." Here, a famous religious authority in Cianjur, which is one of the five leading sending areas in Indonesia, mentions migrant women's sexuality in terms of Islam:

"If women work abroad alone, it might greatly increase the possibility of abuse in the destination country. If they are alone abroad, sexual abuse especially brings discredit to not only their [the victim's] husband but also their parents. As a consequence of being labor migrants overseas, this is quite humiliating. However, we all know their family, including the migrant women. We, who are Islamic, cannot mention the male family member's responsibility. All migrant women, that is, their wives understand too [...]

What else can we do? In this village, try as we may, we cannot afford to send kids to school by ourselves only by working in agriculture. "

'Aalim, who is himself the "husband of a domestic worker," made the above, statement because male family members of domestic workers are generally silent. Men who are stigmatized as the "husband of a domestic worker" often keep silent as they are embarrassed to be singled out by local religious authorities and men in urban areas.

We can see the contrast between "those who migrate" and "those who do not migrate" whenever a woman's body becomes a social issue. In Indonesia, since the 1980s, we have seen the same pattern of representation of women's body. In the late 1980s, there was conflict over the issue of migrant women in Saudi Arabia between the Ulema Council and the Ministry of Manpower and Transmigration; in 2008, the issue of the Anti-Porn draft was debated in regard to the definition of porn; in 2010, there was debate about lone overseas domestic workers. Eyes for the orang biasa (ordinary people) deploys the same construction in the face of the stigmatization of women's body, that is, they are embarrassed and remain silent.

\section{Which women go to the Gulf countries to work: avoidance of deviation}

The discourses of migrant women impose a stigma on migrant women and their male family members. How do these discourses and the reaction of the men in their families have an impact on the daily routine of returning migrant women? First, women's labor outside the home is not unusual. As described above, agriculture, especially rice and corn cultivation, is the main industry in A village, and most women and men have been engaged in agricultural work as owners and peasant farmers. Therefore, there is no stigma as far as women in the workforce in the sending community are concerned.

However, outside of the community, migrants and their families are evaluated in low terms. Women are seen as "economically 'poor' and 'low' class 
women who have to go abroad as domestic workers," and when it comes to their going to the Gulf countries, this view takes on different shades in that the sexual dimension is emphasized.

Women try to avoid these negative perceptions by performing the roles of wife and mother devotedly within customary religious norms. As George points out, migrant women avoid deviating from the norm and being stigmatized by intentionally maintaining the expected gender roles in their community (George, [2005] 2011). We have seen in the case of A village that migrant women describe their body as dosa, and haram, at the same time they tend to stress that they perform the roles of wife, mother, and reproductive laborer inordinately on their own:

"I would not let my children and husband do domestic work, as [I] would come back home poor rather than let them do such things. "

In the private sphere, they do not insist on their own earned income, but rather focus on their performance of the obligatory gender roles.

However, we can discover different aspects of women's conduct in the sending community in comparison to their behavior during the period before they went abroad. Below, we discuss two cases of ex-migrant women who moved voluntarily and made changes in customary practices.

In this sending community, return migrants have made compulsory donations to the village office since the early 2000s. It is easy to know when migrant workers will return if one lives in the community. Once the migrants' return is determined, that news soon causes tongues to wag in the community, in which the inhabitants have kinship with each other. If the staff of the village office catches the news of the return, they collect the mandatory donations by visiting the return migrants' homes to claim desks, chairs, and equipment for the office. The public eye is focused on this negotiation so that none of the return migrants can refuse this "official" request and so that they will donate 100,000 or 200,000 rupiah every time they return.

However, the voluntary approach by ex-migrant women led to the discontinuation of this custom that is related to international migration. The women said, "We have continued doing tough work to afford things for our families, so why do we have to make donations for nonrelated items? We are pleased to put our hands in our pockets if the donations are for the mosque. You know, the office actually has enough budget that it can afford this." Most equipment in the village office is financed by these donations, yet now, no one visits the migrants' homes on their return.

Other cases can also be cited. Ex-migrant workers feel that this issue is one in which all the members of the entire community should take action. All Indonesian people older than 17 years must carry the kartu tanda penduduk (resident registry document: KTP) ${ }^{20}$. Officially, this document is free of charge; however, residents who were issued this identification, especially migrant

20 The KTP contains the following information: name, birth date, origin, gender, religion, current address, occupation, blood type, etc. Although every year after 
women's families, in A village were required to pay 100,000 rupiah as a processing fee. In addition, the current government has stated that medical fees should be free for the poor who have a card signifying that they are a poor family. However, in A village it was necessary to obtain a referral letter from the head of the neighborhood community association or the village office, which moreover, charged 50,000 rupiah for issuing the letter. The appeal to the village head by the return migrants provided an opportunity to have a meeting several times between the women and the village office staff, and as it turned out, the processing fee for migrants' families was stipulated in the relevant regulations, and the poor were treated free of charge.

At the community level, migrant women sometimes subjectively take action, which is worth highlighting. Through migrant women's own discourses concerning their own body, they try, on the one hand, to negotiate or build on practices to avoid being stigmatized for "deviating" from the norm, and on the other hand, regarding events that are not relevant to religious discourses we are going to see that migrant women will be perceived to be an agency on their own.

\section{Conclusion}

In this paper, I have examined how the mechanism of sexual and class stigma toward migrant women, and their male family members occurred in association with the overseas migration of lone women migrants, in terms of both actors' practices in the sending community. The analysis in this paper has proven that stigmatization toward male family members is inextricably associated with stigmatization toward migrant women. Moreover, we identified either sexual or class stigmatization, and the process of their transformation, toward domestic workers. It is apparent that the migrant women's body is the point of dispute from the perspective of labor that configures the gender order in the sending community.

We confirmed that religious accusations are made against lone married women who undertake migration. That is, the content of these accusations is that the body that is on the move is considered dosa (sin). Considering that various social apparatuses strengthen these discourse functions, I discussed local regulations that seek to uphold normative ethics in the realm of religion, as characterized by religious leaders at the local level who allege that the international migration of lone women is a sin. Indonesia is not an Islamic but rather a secular state; however, we find that religion there provides a reference point for daily practices, and moreover, that people place a heavy emphasis on the day-to-day religious order under decentralization as part of Indonesian democratization, and that this has led to local regulations that take on a religious character. Women in the sending community employ certain strategies to deal with these social forces, such as getting divorced before migrating to avoid social sanctions toward their own sinful body (alleviation of religious sin), and

Ramadan many people from rural areas come to the Jakarta metropolitan area, the metropolitan government can set limits on the number who may come in by requiring this identification card. It is also used to impose a resident tax. The Department of Home Affairs issued a letter regarding religion. That is, this form does not have to be filled in, starting in December 2013. 
inordinately asserting their own sinful position, thus embedding themselves into a second-class status. These women now have more economic power in their hands than in the past, but to avoid deviating from the norm, they insist that their husbands are still in the household head position, although they are not the breadwinner.

Meanwhile, the male spouses of migrant women, who "descend" from their breadwinner position, have been perceived as demasculinized and are despised in the eyes of men in urban areas. In fact, men in urban areas and in the middle class conform to society's norms by demasculinizing the men who are left behind by migrant women, calling them by a pejorative, "domestic workers' husbands," who force their spouses to move away and send their salary home. The "domestic workers' husbands" do not respond to this insult.

Concerning the prescribing of gender relations within the home, we need, on the one hand, to pay attention to the role of the mosque, where people have been taught gender roles in accordance with the Koran since childhood. Islamic religious leaders generally do not mention the reversed position of the breadwinner, which is the result of overseas migration. These leaders only tell the men who are left behind by migrant women not to reverse the gender roles within the household, such as doing all the housework and childrearing, but rather to remain honest and not cheat on their partners, which will prevent them from having to divorce their wives after they return. Migrant women and their male family members, and "unmobile people" make and strengthen the discourse of dosa, which is embodied in the sending household and community. This occurs in line with the establishment of the migrant labor business circuit in the sending community that is part of the advancement of globalization. The sexual stigmatization of lone women who migrate is a "classic" issue, same as sexual norms configured by the transnational movement of persons as the religious leaders' teaching.

I have discussed these gendered daily practices in this sending community in accordance with the theoretical framework of the "gender regime" proposed by Connell (2002). This paper focused mainly on the fields of "labor" and "community." In the field of "labor," we found that, although migrant women have economic power as the substantive household breadwinner, first, as domestic workers they are categorized in the informal sector, and second, their moving to the Gulf countries imposes a sexual stigma on them. Moreover, returned migrant women play active roles as mothers and wives in their community to avoid this stigmatization. In the community field, we found the reproduction of gender relations through religious teaching, which forms the various gender norms described above. It is clear that the multistrata crossinteraction between the fields of labor and community strengthens the sexual stigmatization of migrant women.

However, at the same time, we should not reduce migrant women's practices to avoid the label of deviation to being a simple scheme. That is, they are held back by the repressive patriarchy in the sending community, and the progress of Islamization in Indonesia causes migrant women to be silent. As described above, the teachings by religious leaders contains the seeds to the transformation of gender roles, which preaches to male family members of migrant 
workers not to cheat on their wives to avoid receiving a claim for divorce when their migrant wives return.

Migrant women accumulate various kinds of experience, such as speaking Arabic and making pilgrimages to sacred places while attending their employers, and these experiences are conducted in the realm of people's daily practices and lead to appreciation of the women. Some migrant women travel alone to several different countries for their work by order of the employer, which builds up their self-esteem and leads to their being active in challenging and transforming conventional practices in the sending community after they return home. They earn the reputation that they have been reborn as active agents.

Furthermore, as to the stigmatization of male family members of migrant workers, especially the "husbands of domestic workers," we need to pay attention to the new movement of men in urban areas who are attempting to construct a new "masculinity". Alilansi laki laki baru (New Men's Alliance) ${ }^{22}$, which is led by young people, is a movement for gender equity. They create new spaces for discussion regarding what masculinity is through online discussions, and in workshops held at universities and community spaces. We can easily see their pro-feminist position because they propose various models for men, such as men who raise their children, men who do housework, men who do not engage in violence toward women, and men who question heterosexuality itself. They show the possibility of taking a counteraction against the model of men in the breadwinner role and vaunt a strong masculinity in Indonesia. The emergence of this movement of men in urban areas who do not stigmatize men in rural areas, presents a challenge toward reconfiguring the notion of masculinity, that is, the gender regime. This process of the transformation of the gender regime in the sphere of migration is a subject that must continually be examined.

\section{References}

Anggraeni Dewi (2006) Dreamseekers: Indonesian Women as Domestic Workers in Asia, Jakarta, Equinox Publisher, 268 p.

Connell Raewyn W. (2002) Gender: Polity Short Introductions (Taga Futoshi translation supervisor, 2008, Jenda gaku no saizensen, Tokyo: Sekai Shisosya), Cambridge, Polity Press, 200 p.

George M. Sheba (2005) When Women Come First: Gender and Class in Transnational Migration (Ruri Ito translation supervisor, 2011, Onna ga saki ni utsuri sumu toki: Zaibei Indo jin kangoshi no transnational na seikatsu sekai, Yusindo), Berkeley, University of California Press, 296 p.

Hirano Keiko (2009)TheTransition of Indonesian Employment Policy for overseas Migrant Workers: A Focus on Feminization of Migration, Globalization of the Reproductive Sphere and Gender Reconfiguration in Asia, pp. 30-48.

22 For details, see their website, http://lakilakibaru.wordpress.com/ 
Hirano Keiko (2013) Indonesian Migrant Domestic Workers "Issue" and the Possibility of Networking Hakusan Jinruigaku, Hakusan, Society of Anthropology, pp. 93-108.

Hochschild Arlie Russell (2000) Global Care Chains and Emotional Surplus Value, in Will Hutton and Anthony Giddens Eds., On the Edge: Living with Global Capitalism, London, Jonathan Cape, p.131.

Indonesia Departemen Penerangan (1985) Rencana Pembangunan Lima Tahun Ke Empat: 1984/85 - 1988/89 (REPELITA IV) (Fourth Five-Year Development Plan 1984/85 - 1988/89), Jakarta, Departemen Penerangan, 810 p.

Ito Ruri and Adachi Mariko (2008) Kokusai Ido to "Rensa suru Gender": Saiseisan ryoiki no global ka (International Migration and "Consecutive Gender": Globalization of Reproduction of Sphere), Tokyo, Sakuhin sya, 272 p.

Irianto Sulistyowati (2011) Akses Keadilan dan Migrasi Global: Kisah Perempuan Indonesia Pekerja Domestik di Uni Emirat Arab (Access to Justice for Indonesian Women Migrant Domestic Workers in the United Arab Emirates), Jakarta, Yayasan Obor Indonesia, 326 p.

Kobayashi Yasuko (2008) Indonesia: Tenkai suru Islam (Indonesia: Unfolding Islam), Nagoya, Nagoya University Press, 479 p.

Miyamoto Kensuke (2000) Kokusai Roudouryoku Idou no Rekishiteki Isou (Historical Dimensions of International Labour Migration), Keizaigaku Kenkyu (Economic Studies), 50 (2), pp. 67-86.

Mulia Siti Musdah (2006) Perda syariat dan peminggiran perempuan: ada apa dengan demokrasi di Indonesia? (Shariah in Local Regulations and Marginalization of Women: What Occurs with Democratization in Indonesia?), paper circulated in emails and on the Internet.

Mulia Siti Musdah (2006b) Islam and Violence Against Women: Promoting Gender Equality in Indonesia, Jakarta, LKAJ, 78 p.

Nurmila Nina (2009) Women, Islam and Everyday Life: Renegotiating Polygamy in Indonesia, London and New York, Routledge, 197 p.

Keichi Kumagai et al. (2007) Beyond the Difference: Repositioning Gender and Development in the Current Indonesia, Beyond the Difference: Repositioning Gender and Development in Asian and the Pacific Context, Proceedings International Workshop for Junior Scholars, Tokyo, Ochanomizu University, pp. 6-7.

Robinson Kathryn (1991) Housemaids: The Effects of Gender and Culture on the Internal and International Migration of Indonesian Women, in Bottomley Gillian et al. Eds., Intersexions: Gender/ Class/ Culture/ Ethnicity, Sydney, Allen \& Unwin, pp. 31-51.

Robinson Kathryn (2000) Gender, Islam and Nationality: Indonesian Domestic Servants in the Middle East, in Adams Kathleen and Dickey Sara Eds., Home and Hegemony: Domestic Service and Identity in South and Southeast Asia, Ann Arbor, Michigan University, pp. 249-282

Sabban Rima (2012) Maids Crossing: Domestic Workers in the UAE, Sarrebruck, Lambert Academic Publishing, 364 p. 
Sasaki Takuo (2004) Tomadoi no Jidai to 'Inur gensyo': Taishu bunka no kanten kara mita Indonesia Musulim syakai no doutai (The Era of Confusion and Inur Phenomenon: Dynamics of Indonesian Muslim in Terms of Popular Culture), Japanese Journal of Southeast Asian studies, 42 (2), pp. 208-230.

Ueno Kayoko (2011) Kokyo wo koeru Asia no kaji roudousya: Onna tachi no seikatsu senryaku (Transnational Asian Domestic Workers: Women's Life Strategy), Tokyo, Sekai Shisosya, 264 p.

Vlieger Antoinette (2012) Domestic Workers in Saudi Arabia and the Emirates: A Socio-legal Study on Conflicts, New Orleans, Quid Pro LLC, 328 p. 


\section{Keiko Hirano}

\section{... When Working Abroad Becomes a Dosa (Sin): The Impact of Women's Migrant Domestic Labor on Gender Relations in Rural Indonesia}

Since the 1980s, the Indonesian government has employed the strategy of sending women migrant workers. How does the policy of sending migrant workers abroad impact gender relations within the migrants' household? This study discusses this question in the context of a village, Cianjur Province West Java in Indonesia, where the author conducted fieldwork. The study elucidated that the sending community makes religious accusations against married women who undertake overseas migration. That is, when women are on the move, their body is considered as dosa (sin). Moreover, as various social apparatuses strengthen these discourse functions, the study discusses local regulations that seek to uphold normative ethics in the name of religion. Women from A village try to overcome this dilemma by producing counter discourses and practices. Furthermore, migrant work by women transforms the masculinity of the spouses of these women. Men in families of migrant women are often called the "husband of a domestic worker." This pejorative term is a code that is generated by the process of globalization.

\section{... Quand travailler à l'étranger devient un péché (Dosa) : L'impact du travail d'employé de maison des femmes immigrées sur les relations entre les hommes et les femmes dans I'Indonésie rurale}

Depuis les années 1980, envoyer des femmes travailler dans des emplois saisonniers à l'étranger est une stratégie du gouvernement indonésien. Quel est l'impact de cette politique sur les relations entre les hommes et les femmes au sein des foyers d'immigrés ? Dans cet article, l'auteure traite de cette question dans le contexte d'un village, dans la province Cianjur à l'ouest de Java en Indonésie, région dans laquelle elle a mené ses recherches. Elle montre que la communauté profère des accusations religieuses à l'encontre des femmes mariées qui entreprennent d'émigrer à l'étranger. Le corps des femmes en déplacement est considéré comme dosa (péché). L'auteure s'intéresse aux règlementations locales qui cherchent à défendre des éthiques normatives au nom de la religion ainsi qu'aux réponses et aux pratiques qu'apportent les femmes. En outre, le travail que les femmes immigrées effectuent transforme la masculinité de leurs époux; les hommes sont souvent appelés le " mari de l'employée de maison ". Ce terme péjoratif est devenu un code qui résulte du processus de mondialisation.

\section{... Cuando trabajar en el extranjero se convierte en un pecado (Dosa): El impacto del trabajo doméstico de las mujeres migrantes sobre las relaciones de género en la Indonesia rural}

Desde los años 80, el gobierno de Indonesia ha empleado la estrategia de enviar a las trabajadoras migrantes al extranjero. ¿En qué forma la política de enviar trabajadores domésticos al extranjero impacta a las relaciones de género dentro del hogar de los migrantes? Este estudio analiza esta pregunta en el contexto de un pueblo, en la provincia de Cianjur, Java Occidental en Indonesia, donde el autor llevó a cabo el trabajo de campo. El estudio estableció que la comunidad de origen emite acusaciones religiosas contra las mujeres casadas que migran 
al extranjero. Es decir, cuando las mujeres están en movimiento, su cuerpo se considera como un dosa (pecado). Además, como existen varios aparatos sociales que fortalecen estas funciones del discurso, el estudio analiza las regulaciones locales que buscan sostener éticas normativas en nombre de la religión. Las mujeres del pueblo A intentan superar este dilema produciendo discursos y prácticas en contrario. Asimismo, el trabajo migrante en el extranjero realizado por mujeres transforma la masculinidad de los cónyuges de estas mujeres. A los hombres en las familias de las mujeres migrantes a menudo se los llama el "marido de una trabajadora doméstica". Este término peyorativo es un código generado por el proceso de la globalización. 